\title{
1 COVID-19 and acute kidney injury in German hospitals
}

\section{0}

3 COVID-19 and AKI in Germany

4

9 Victor Walendy ${ }^{1}$, Matthias Girndt ${ }^{1}$, Daniel Greinert ${ }^{1}$

12 Department of Internal Medicine II

13 Medical Faculty of the

14 Martin-Luther-University Halle-Wittenberg

15 Ernst-Grube-Straße 40

16 D-06120 Halle (Saale)

17 Germany

18

19 Corresponding author:

20 Victor.walendy@uk-halle.de 
medRxiv preprint doi: https://doi.org/10.1101/2021.04.30.21256331; this version posted June 4, 2021. The copyright holder for this preprint

(which was not certified by peer review) is the author/funder, who has granted medRxiv a license to display the preprint in perpetuity.

It is made available under a CC-BY-NC-ND 4.0 International license .

\section{Abstract}

\section{Introduction}

24 The SARS-CoV-2 pandemic is a major challenge for patients, healthcare professionals, and

25 populations worldwide. While initial reporting focused mainly on lung involvement, the

26 ongoing pandemic showed that multiple organs can be involved, and prognosis is largely

27 influenced by multi-organ involvement. Our aim was to obtain nationwide retrospective

28 population-based data on hospitalizations with COVID-19 and AKI.

\section{Materials \& Methods}

30 We performed a query of G-DRG data for the year 2020 via the Institute for the hospital

31 remuneration system (Institut für das Entgeltsystem im Krankenhaus $\mathrm{GmbH}$, InEK) data

32 portal and therefore included hospitalizations with a secondary diagnosis of RT-PCR proven

33 COVID-19 infection, aged over 15 years. We included hospitalizations with acute kidney

34 injury (AKI) stages 1 to 3. Age-specific and age-standardized hospitalization and in-hospital

35 mortality rates (ASR) per 100.000 person years were calculated, with the German

36 population of 2011 as the standard.

\section{Results}

38 In 2020, there were 16.776 .845 hospitalizations in German hospitals. We detected 154.170

39 hospitalizations with RT-PCR proven COVID-19 diagnosis. The age-standardized

40 hospitalization rate for COVID-19 in Germany was 232,8 per 100.000 person years (95\% Cl

$41231,6-233,9)$. The highest proportion of hospitalizations associated with COVID-19 were in

42 the age group over 80 years. AKI was diagnosed in $16.773(10,9 \%)$ of the hospitalizations 
medRxiv preprint doi: https://doi.org/10.1101/2021.04.30.21256331; this version posted June 4, 2021. The copyright holder for this preprint (which was not certified by peer review) is the author/funder, who has granted medRxiv a license to display the preprint in perpetuity.

It is made available under a CC-BY-NC-ND 4.0 International license .

43 with COVID-19. The relative risk of AKI for males was $1,49(95 \% \mathrm{Cl} 1,44-1,53)$ compared to

44 females. Renal replacement therapy (RRT) was performed in 3.443 hospitalizations, 20,5\%

45 of the hospitalizations with AKI. For all hospitalizations with COVID-19, the in-hospital

46 mortality amounted to $19,7 \%(n=30.300)$. The relative risk for in-hospital mortality was 3,87

$47(95 \% \mathrm{Cl} 3,80-3,94)$ when AKI occurred. The age-standardized hospitalization rates for COVID-

4819 took a bimodal course during the observation period. The first peak occurred in April

49 (ASR 23,95 per 100.000 person years $(95 \% \mathrm{Cl} 23,58-24,33)$ ), hospitalizations peaked again in

50 November $2020(72,82$ per 100.000 person years $(95 \% \mathrm{Cl} 72,17-73,48))$. The standardized

51 rate ratios (SRR) for AKI and AKI-related mortality with the overall ASR for COVID-19

52 hospitalizations in the denominator, decreased throughout the observation period and

53 remained lower in autumn than they were in spring. In contrast to all COVID-19

54 hospitalizations, the SRR for overall mortality in COVID-19 hospitalizations diverged from

55 hospitalizations with AKI in autumn 2020.

\section{Discussion}

57 Our study for the first time provides nationwide data on COVID-19 related hospitalizations

58 and acute kidney injury in Germany in 2020. AKI was a relevant complication and associated

59 with high mortality. We observed a less pronounced increase in the ASR for AKI-related

60 mortality during autumn 2020. The proportion of AKI-related mortality in comparison to the

61 overall mortality decreased throughout the course of the pandemic.

62

63 
medRxiv preprint doi: https://doi.org/10.1101/2021.04.30.21256331; this version posted June 4, 2021. The copyright holder for this preprint (which was not certified by peer review) is the author/funder, who has granted medRxiv a license to display the preprint in perpetuity. It is made available under a CC-BY-NC-ND 4.0 International license .

\section{Introduction}

65 The SARS-CoV-2 pandemic is a major challenge for patients, healthcare professionals, and

66 populations worldwide. While initial reporting focused mainly on lung involvement, the

67 ongoing pandemic showed that multiple organs can be involved, and prognosis is largely

68 influenced by multi-organ involvement. According to published data, the kidney is the

69 second most involved organ. In a study from the New York City area, 22,2\% of hospitalized

70 patients showed acute kidney injury (AKI)(1). A meta-analysis (2) confirmed the high AKI

71 rate among COVID-19 patients. In contrast to this, there is also data with lower incidence of

$72 \operatorname{AKI}(3,4)$ especially early analysis from Wuhan, China did not show high incidence rates of

73 AKI (3-5). However, different definitions of AKI complicate comparability. In critically ill

74 patients with COVID-19 as many as 55 to $90 \%$ experienced AKI (6-8), of whom 21 to $37 \%$

75 required renal replacement therapy $(\mathrm{RRT})(6,8,9)$. The mortality rates of patients with acute

76 kidney injury are significantly higher than in patients without AKI. In a study by Chan et al.

77 (9), the in-hospital mortality was $50 \%$ among patients with, versus $8 \%$ among those without

78 AKI. An analysis by Fisher et al. (8) found similar mortality rates (52\% vs. $19.6 \%$ ). In addition,

79 the length of stay (LOS) was markedly prolonged when AKI occurred $(9,10)$.

80 The German healthcare system offers comprehensive insurance coverage and, by

81 international comparison, a high level of healthcare services. Throughout the COVID-19

82 pandemic there were no apparent acute care resource limitations, and the hospital

83 capacities were at their limit but not overwhelmed. Nationwide unselected data, especially

84 covering a longer time interval is not available. There is one observational study, which

85 included 10.021 hospitalizations (11). The data from this study was obtained from one 
medRxiv preprint doi: https://doi.org/10.1101/2021.04.30.21256331; this version posted June 4, 2021. The copyright holder for this preprint

(which was not certified by peer review) is the author/funder, who has granted medRxiv a license to display the preprint in perpetuity.

It is made available under a CC-BY-NC-ND 4.0 International license .

86 German health insurance company and covered a short period of time (from February 26

87 until April 19, 2020). In this study, AKI was not addressed.

88 Our aim was to obtain nationwide retrospective population-based data on hospitalizations

89 with COVID-19 and AKI. Our query covered data from the year 2020 and contains, to our

90 knowledge, the most comprehensive data regarding patients with COVID-19 and AKI in

91 Germany.

92 Materials \& Methods

93 Data Source

94 In accordance with the German Hospital Financing Act (KHG), a universal, performance-

95 based remuneration system was introduced for general hospital services. The basis for this

96 is the German-Diagnosis Related Groups system (G-DRG system), whereby each inpatient

97 case of treatment is remunerated by means of a corresponding DRG rate. All hospitals

98 submit their hospitalization data to the Institute for the hospital remuneration system

99 (Institut für das Entgeltsystem im Krankenhaus $\mathrm{GmbH}$, InEK). After submission, a plausibility

100 control of the data is carried out by InEK. The submission of hospitalization data is

101 mandatory for reimbursement of hospital stays. This leads to a strong incentive for hospitals

102 to supply complete data, covering virtually every hospital in Germany. The transferred data

103 include information on age, sex, discharge type, primary and secondary ICD-10-GM(12)

104 coded diagnosis (International Classification of Diseases, 10th Edition, German Modification

105 Version 2020) and performed operations and procedures (Operationen- und

106 Prozedurenschlüssel Version 2020, OPS) (13). We performed a query of G-DRG data for the

107 year 2020 via the InEK data portal (https://datenbrowser.inek.org/). The InEK data are 
medRxiv preprint doi: https://doi.org/10.1101/2021.04.30.21256331; this version posted June 4, 2021. The copyright holder for this preprint (which was not certified by peer review) is the author/funder, who has granted medRxiv a license to display the preprint in perpetuity.

It is made available under a CC-BY-NC-ND 4.0 International license .

108 available in aggregated form, so that differentiation by federal state is not possible.

109 Differentiation by age can only be made in the predefined age groups and differentiation by

110 gender only indirectly. The G-DRG data provided by InEK have been described in detail

111 elsewhere (14).

\section{Cohort selection}

113 We included hospitalizations with a secondary diagnosis of RT-PCR proven COVID-19

114 infection (ICD-10-GM: U07.1), aged over 15 years. We excluded hospitalizations 15.525

$115(9,1 \%)$ with hospital transfer and unknown discharge status from our analysis. We identified

116 hospitalizations with acute kidney injury by their corresponding ICD-10-GM codes (S1

117 Table). We included hospitalizations with acute kidney injury stages 1 to 3 (AKIN 1 to 3) (15).

118 We further searched for OPS codes indicating hemodialysis and mechanical ventilation (S1

119 Table). The survival status at the end of each hospitalization was obtained by discharge

120 type. The observation period was from 01.02.2020 throughout 31.12.2020.

\section{Statistical analysis}

122 We calculated crude, age-specific and age-standardized hospitalization rates (ASR) per

123100.000 person years and the respective $95 \%$ confidence intervals $(95 \% \mathrm{Cl})$. We used the

124 standard population of Germany in 2011 (16), provided by the Federal Bureau of Statistics

125 (DESTATIS), for direct age-standardization (S2 Table). We further calculated standardized

126 rate ratios (SRR), with their respective confidence intervals. Continuous variables are

127 reported with standard deviation (SD). Categorical data is reported in absolute numbers and

128 percentages. We used the ICD-10 version of the Elixhauser comorbidity index (ECI) to assess

129 comorbidities (17). We excluded acute kidney injury as a comorbidity. All data analysis was 
medRxiv preprint doi: https://doi.org/10.1101/2021.04.30.21256331; this version posted June 4, 2021. The copyright holder for this preprint (which was not certified by peer review) is the author/funder, who has granted medRxiv a license to display the preprint in perpetuity. It is made available under a CC-BY-NC-ND 4.0 International license.

130 carried out using R (Version 3.6.3) (18), for direct age-standardization the epitools package

131 (19) was used, contingency tables were evaluated using the epiR package (20). 
medRxiv preprint doi: https://doi.org/10.1101/2021.04.30.21256331; this version posted June 4, 2021. The copyright holder for this preprint (which was not certified by peer review) is the author/funder, who has granted medRxiv a license to display the preprint in perpetuity.

It is made available under a CC-BY-NC-ND 4.0 International license.

8

\section{Results}

\section{General characteristics and age-standardized rates}

134 In 2020, there were 16.776 .845 hospitalizations in German hospitals. We detected 154.170

135 hospitalizations with RT-PCR proven COVID-19 diagnosis throughout the observation period.

136 There were $79.781(51,8 \%)$ male and $74.382(48,2 \%)$ female patients hospitalized,

137 respectively (Table 1$)$. In $29.329(19,0 \%)$ of the COVID-19 associated hospitalizations the

138 treatment included an intensive care unit (ICU) stay. The age-standardized hospitalization

139 rate for COVID-19 in Germany was 232,8 per 100.000 person years (95\% Cl 231,6-233,9) in

140 2020. Most hospitalizations (1394,1 per 100.000 person years) occurred in the age group of

14180 years and older (Fig 1).

142

143 
medRxiv preprint doi: https://doi.org/10.1101/2021.04.30.21256331; this version posted June 4, 2021. The copyright holder for this preprint (which was not certified by peer review) is the author/funder, who has granted medRxiv a license to display the preprint in perpetuity. It is made available under a CC-BY-NC-ND 4.0 International license.

\begin{tabular}{|c|c|c|c|c|c|c|}
\hline & \multicolumn{2}{|l|}{ AKI } & \multicolumn{2}{|l|}{ ICU } & \multicolumn{2}{|l|}{ Overall } \\
\hline $\mathrm{N}$ & \multicolumn{2}{|c|}{16.773} & \multicolumn{2}{|c|}{29.329} & \multicolumn{2}{|c|}{154.170} \\
\hline Gender & $\%$ & $n$ & $\%$ & $n$ & $\%$ & $n$ \\
\hline male & \multicolumn{2}{|c|}{$61,5(10.308)$} & \multicolumn{2}{|c|}{$62,6(18.361)$} & \multicolumn{2}{|c|}{$51,8(79.781)$} \\
\hline female & \multicolumn{2}{|c|}{$38,5(6.463)$} & \multicolumn{2}{|c|}{$37,4(10.965)$} & \multicolumn{2}{|c|}{$48,2(74.382)$} \\
\hline Age group (years) & $\%$ & $n$ & $\%$ & $n$ & $\%$ & $n$ \\
\hline $16-17$ & $0,0 \%$ & 1 & $0,1 \%$ & 38 & $0,3 \%$ & 472 \\
\hline $18-29$ & $0,4 \%$ & 70 & $1,7 \%$ & 493 & $4,0 \%$ & 6143 \\
\hline $30-39$ & $0,7 \%$ & 112 & $2,8 \%$ & 829 & $5,3 \%$ & 8185 \\
\hline $40-49$ & $1,9 \%$ & 326 & $5,8 \%$ & 1704 & $7,5 \%$ & 11601 \\
\hline $50-54$ & $2,6 \%$ & 443 & $5,8 \%$ & 1688 & $6,2 \%$ & 9537 \\
\hline $55-59$ & $4,5 \%$ & 754 & $7,9 \%$ & 2312 & $7,5 \%$ & 11602 \\
\hline $60-64$ & $6,8 \%$ & 1134 & $9,6 \%$ & 2818 & $7,7 \%$ & 11858 \\
\hline $65-74$ & $20,3 \%$ & 3408 & $21,8 \%$ & 6398 & $16,5 \%$ & 25418 \\
\hline $75-79$ & $17,0 \%$ & 2851 & $14,6 \%$ & 4282 & $11,7 \%$ & 18045 \\
\hline $80+$ & $45,8 \%$ & 7674 & $29,9 \%$ & 8767 & $33,3 \%$ & 51309 \\
\hline $\begin{array}{l}\text { length of stay (days, } \\
\text { SD) }\end{array}$ & \multicolumn{2}{|c|}{$18,4(16,9)$} & \multicolumn{2}{|c|}{$18,3(16,7)$} & \multicolumn{2}{|c|}{$11,3(11,9)$} \\
\hline $\begin{array}{l}\text { Elixhauser } \\
\text { comorbidity index }(\% \text {, } \\
\text { n) }\end{array}$ & $\%$ & $n$ & $\%$ & $n$ & $\%$ & $n$ \\
\hline 0 & \multicolumn{2}{|c|}{$60(10.041)$} & \multicolumn{2}{|c|}{65 (18.918) } & \multicolumn{2}{|c|}{65 (99.783) } \\
\hline $1-4$ & \multicolumn{2}{|c|}{$24(4.029)$} & \multicolumn{2}{|c|}{$25(7.186)$} & \multicolumn{2}{|c|}{25 (39.117) } \\
\hline$>=5$ & \multicolumn{2}{|c|}{$16(2.703)$} & \multicolumn{2}{|c|}{$10(3.225)$} & \multicolumn{2}{|c|}{$10(15.270)$} \\
\hline mean (SD) & \multicolumn{2}{|c|}{$2,0(3,8)$} & \multicolumn{2}{|c|}{$1,6(3,8)$} & \multicolumn{2}{|c|}{$1,2(3,1)$} \\
\hline
\end{tabular}

151 Table 1. General characteristics of COVID-19 hospitalizations in Germany 2020.

152 ICU: intensive care unit - hospitalizations with intensive care treatment during the hospital

153 stay, AKI: acute kidney injury - hospitalizations with acute kidney injury (Acute kidney injury

154 network Stage 1-3), SD: standard deviation 
medRxiv preprint doi: https://doi.org/10.1101/2021.04.30.21256331; this version posted June 4, 2021. The copyright holder for this preprint (which was not certified by peer review) is the author/funder, who has granted medRxiv a license to display the preprint in perpetuity. It is made available under a CC-BY-NC-ND 4.0 International license.

156 Fig 1. Age-specific rates of COVID-19 hospitalizations in Germany 2020 (per 100.000 person

157 years) 
medRxiv preprint doi: https://doi.org/10.1101/2021.04.30.21256331; this version posted June 4, 2021. The copyright holder for this preprint (which was not certified by peer review) is the author/funder, who has granted medRxiv a license to display the preprint in perpetuity.

It is made available under a CC-BY-NC-ND 4.0 International license .

158 Hospital incidence of acute kidney injury

159 Acute kidney injury, including AKI Stages 1-3, was diagnosed in $16.773(10,9 \%)$ of the

160 hospitalized cases with COVID-19. The ASR for AKI was 25.8 (95\% CI 25.4-26.2) per 100.000

161 person years (Table 2). While men and women were equally distributed among those

162 hospitalized for COVID-19, men were more affected by AKI than women. The relative risk of

163 AKI for males was $1,49(95 \% \mathrm{Cl} 1,44-1,53)$ compared to females hospitalized with COVID-19

164 (S2 Table). We determined $10.310(61,5 \%)$ male and $6.463(38,5 \%)$ female hospitalizations

165 with acute kidney injury, respectively (Table 1). The proportion of the severity of acute

166 kidney injury was distributed as follows: $32,0 \%(n=5.407)$ developed AKI Stage 1, AKI Stage

1672 was present in $27,4 \%(n=4.625)$ and in $40,6 \%(n=6.842)$ AKI Stage 3 was coded. There

168 were 101 hospitalizations with more than one code for AKI. When acute kidney injury was

169 present during hospital stay, $8.374(49,9 \%)$ needed intensive care. Furthermore, mechanical

170 ventilation was required in 7.050 (42,0 \%) hospitalizations with acute kidney injury (Table 2).

171 The relative risk for hospitalizations with AKI to be treated in an intensive care unit was 3,27

$172(95 \% \mathrm{Cl} 3,21-3,34)$ (Table 3). 
medRxiv preprint doi: https://doi.org/10.1101/2021.04.30.21256331; this version posted June 4, 2021. The copyright holder for this preprint (which was not certified by peer review) is the author/funder, who has granted medRxiv a license to display the preprint in perpetuity. It is made available under a CC-BY-NC-ND 4.0 International license .

\begin{tabular}{|c|c|c|c|c|c|c|}
\hline & \multicolumn{2}{|l|}{ AKI } & \multicolumn{2}{|l|}{ ICU } & \multicolumn{2}{|l|}{ Overall } \\
\hline & $\mathrm{n}$ & $\%$ & $\mathrm{n}$ & $\%$ & $\mathrm{n}$ & $\%$ \\
\hline Overall & \multicolumn{2}{|c|}{$16.773(10,9 \%)$} & \multicolumn{2}{|c|}{$29.329(19,0 \%)$} & \multicolumn{2}{|c|}{$154.170(-)$} \\
\hline $\begin{array}{l}\text { Renal replacement } \\
\text { therapy }\end{array}$ & \multicolumn{2}{|c|}{$3.443(20,5 \%)$} & \multicolumn{2}{|c|}{$3.046(10,4 \%)$} & \multicolumn{2}{|l|}{-} \\
\hline males & 2.635 & $76,5 \%$ & 2.335 & $76,7 \%$ & - & - \\
\hline females & 808 & $23,5 \%$ & 711 & $23,3 \%$ & - & - \\
\hline In-hospital mortality & \multicolumn{2}{|c|}{$9.717(57,9 \%)$} & \multicolumn{2}{|c|}{$12.322(40,6 \%)$} & \multicolumn{2}{|c|}{$30.300(19,7 \%)$} \\
\hline males & 6.283 & $64,7 \%$ & 7.990 & $64,8 \%$ & 17.635 & $58,2 \%$ \\
\hline females & 3.434 & $35,3 \%$ & 4.330 & $35,2 \%$ & 12.665 & $41,8 \%$ \\
\hline \multicolumn{7}{|l|}{ AKI Stages } \\
\hline 1 & 5.407 & $32,0 \%$ & 1.865 & $20,3 \%$ & - & \\
\hline 2 & 4.625 & $27,4 \%$ & 2.011 & $21,8 \%$ & - & \\
\hline 3 & 6.842 & $40,6 \%$ & 5.333 & $57,9 \%$ & - & \\
\hline $\begin{array}{l}\text { Chronic kidney } \\
\text { disease }\end{array}$ & \multicolumn{2}{|c|}{$5.524(32,9 \%)$} & \multicolumn{2}{|c|}{$5.365(18,3 \%)$} & \multicolumn{2}{|c|}{$23.380(15,2 \%)$} \\
\hline G3 & 3.638 & $21,7 \%$ & 3.225 & $11,0 \%$ & 15.270 & $9,9 \%$ \\
\hline G4 & 1.490 & $8,9 \%$ & 1.084 & $3,7 \%$ & 4.535 & $2,9 \%$ \\
\hline G5 & 396 & $2,4 \%$ & 1.056 & $3,6 \%$ & 3.575 & $2,3 \%$ \\
\hline $\begin{array}{l}\text { Mechanical } \\
\text { ventilation }\end{array}$ & \multicolumn{2}{|c|}{$7.050(42,0 \%)$} & \multicolumn{2}{|c|}{$17.144(58,5 \%)$} & \multicolumn{2}{|c|}{-} \\
\hline males & 5.052 & $71,6 \%$ & 11.508 & $67,1 \%$ & - & \\
\hline females & 1.998 & $28,3 \%$ & 5.634 & $32,9 \%$ & - & \\
\hline $\begin{array}{l}\text { Age-standardized rate } \\
\text { (per } 100.000 \text { PYRs, } \\
95 \% \mathrm{Cl} \text { ) }\end{array}$ & \multicolumn{2}{|c|}{$25,8(25,4-26,2)$} & \multicolumn{2}{|c|}{$44,0(43,5-44,5)$} & \multicolumn{2}{|c|}{$232,8(231,6-233,9)$} \\
\hline
\end{tabular}

173

174 Table 2: Results COVID-19 hospitalizations in Germany 2020,

175 ICU: intensive care unit - hospitalizations with intensive care treatment during the hospital

176 stay, AKI: acute kidney injury - hospitalizations with acute kidney injury (acute kidney injury

177 network, Stage 1-3), 95\%Cl: $95 \%$ confidence interval, PYRs: person years

178 
medRxiv preprint doi: https://doi.org/10.1101/2021.04.30.21256331; this version posted June 4, 2021. The copyright holder for this preprint (which was not certified by peer review) is the author/funder, who has granted medRxiv a license to display the preprint in perpetuity. It is made available under a CC-BY-NC-ND 4.0 International license .

180

\begin{tabular}{|c|c|c|c|c|c|}
\hline & \multicolumn{2}{|c|}{$\mathrm{ICU}$} & \multicolumn{2}{|c|}{ Non-ICU } & Overall \\
\hline & $\mathrm{N}$ & $\%$ & $\mathrm{~N}$ & $\%$ & $n$ \\
\hline AKI & 8.374 & 49,9 & 8.399 & 50,1 & 16.773 \\
\hline Non-AKI & 20.955 & $15,3 \%$ & 116.442 & $84,7 \%$ & 137.397 \\
\hline \multirow[t]{3}{*}{ Overall } & 29.329 & $19,0 \%$ & 124.841 & $81,0 \%$ & 154.170 \\
\hline & \multicolumn{2}{|c|}{ Deceased } & \multicolumn{2}{|c|}{ Alive } & Overall \\
\hline & $N$ & $\%$ & $\mathrm{~N}$ & $\%$ & $\mathrm{~N}$ \\
\hline AKI & 9.717 & $57,9 \%$ & 7.056 & $42,1 \%$ & 16.773 \\
\hline Non-AKI & 20.583 & $15,0 \%$ & 116.814 & $85,0 \%$ & 137.397 \\
\hline Overall & 30.300 & $19,7 \%$ & 123.870 & $80,3 \%$ & 154.170 \\
\hline
\end{tabular}

181

182 Table 3: Contingency table for AKI and risk of ICU admission or in-hospital mortality,

183 ICU: intensive care unit - hospitalizations with intensive care treatment during the hospital

184 stay, AKI: acute kidney injury - hospitalizations with acute kidney injury (acute kidney injury

185 network, Stage 1-3) 
medRxiv preprint doi: https://doi.org/10.1101/2021.04.30.21256331; this version posted June 4, 2021. The copyright holder for this preprint (which was not certified by peer review) is the author/funder, who has granted medRxiv a license to display the preprint in perpetuity.

It is made available under a CC-BY-NC-ND 4.0 International license .

187 When acute kidney injury was present, renal replacement therapy (RRT) was performed in

1883.443 hospitalizations, $20,5 \%$ of hospitalizations with AKI and 2,2\% of all COVID-19

189 associated hospitalizations. Furthermore, when RRT was conducted, mechanical ventilation

190 was needed in $2.380(69,1 \%)$ cases. The modality of renal replacement therapy was

191 intermittent RRT in $230(6,7 \%)$, and continuous or prolongend intermittend RRT in 3.213

192 (93,3\%) hospitalizations, respectively. In 828 (24,0\%) hospitalizations more than one 193 procedure code indicating RRT was present.

194 Chronic kidney disease (CKD Stages 3 to 5) was present in 23.380 (15.2\%) hospitalizations 195 with AKI. We observed 3.638 (21,7\%) hospitalizations with AKI and CKD Stage G3, in 1.490 196 (8.9\%) hospitalizations CKD G4 was prevalent and $396(2,4 \%)$ had CKD G5, respectively.

199 For all hospitalizations with COVID-19, the in-hospital mortality amounted to $19,7 \%$ ( $n=$ 200 30.300). Of these, $58,2 \%(n=17.635)$ were men and $41,8 \%(n=12.665)$ were women (Table

$2012)$, respectively. The relative risk for in-hospital mortality for men amounted to 1,30 (95\% Cl 202 1,27-1,33) compared to women (S3 Table). The ASR for in-hospital mortality was 47,7 203 (95\% Cl 47,2-48,3) per 100.000 person years. Most deaths (511,2 per 100.000 person years) 204 were observed in the age group over 80 years of age (Fig S1). When AKI was present, 9.717 205 died, accounting for $57,9 \%$ of deaths in this group (Table 2 ), the relative risk for in-hospital 206 mortality was 3,87 $(95 \% \mathrm{Cl} 3,80-3,94)$ when AKI occurred (Table 3). Moreover, when 207 hemodialysis was performed, 2.891 died, which amounts to $61,4 \%$ of all hospitalizations 208 with RRT. 
medRxiv preprint doi: https://doi.org/10.1101/2021.04.30.21256331; this version posted June 4, 2021. The copyright holder for this preprint (which was not certified by peer review) is the author/funder, who has granted medRxiv a license to display the preprint in perpetuity.

It is made available under a CC-BY-NC-ND 4.0 International license .

211 The mean length of stay (LOS) for hospitalizations with COVID-19 was 11,3 days (SD 11,9).

212 When acute kidney injury was coded, the LOS increased to 18,4 days (SD 16,9). For cases

213 that had an ICU stay the mean LOS was 18,3 days (SD 16,7) (Table 1).

214 Time course of hospitalization rates and in-hospital mortality

215

216 The age-standardized hospitalization rates for COVID-19 took a bimodal course during the

217 observation period. The first peak of ASR occurred in April 2020 (23,95 per 100.000 person

218 years $(95 \% \mathrm{Cl} 23,58-24,33))$, after the ASR rose steadily beginning in February. Subsequently,

219 ASR for COVID-19 hospitalizations peaked again in November 2020 (72,82 per 100.000

220 person years $(95 \% \mathrm{Cl} 72,17-73,48))$. In comparison to the first peak, ASR rose steadily for two

221 months before reaching the highest rates (Fig 2A).

222 The ASR for AKI and AKI-related mortality took a flatter curve, but overall follow a similar

223 bimodal course. The ASR for AKI and AKI-related mortality reached their peak in March 2020

224 (for AKI 3,4 per 100.000 person years $(95 \% \mathrm{Cl} 3,27-3,55)$, which was also when AKI-related

225 mortality reached 2,07 (95\%Cl 1,96-2,18), respectively). In November 2020 ASR tipped again

226 when ASR for AKI stood at 8,07 per 100.000 person years $(95 \% \mathrm{Cl} 7,85-8,29)$, and the ASR for

227 AKI-related mortality rose to $4,65(95 \% \mathrm{Cl} 4,49-4,82))$ (Fig $2 \mathrm{~A})$.

228 The standardized rate ratios (SRR) for AKI and AKI-related mortality with the overall ASR for

229 COVID-19 hospitalizations in the denominator, actually decreased throughout the

230 observation period (Fig 2B) and remained lower in autumn than they were in spring. In 
medRxiv preprint doi: https://doi.org/10.1101/2021.04.30.21256331; this version posted June 4, 2021. The copyright holder for this preprint (which was not certified by peer review) is the author/funder, who has granted medRxiv a license to display the preprint in perpetuity. It is made available under a CC-BY-NC-ND 4.0 International license .

231 contrast to this finding, the ASR and in particular the SRR for overall mortality in COVID-19

232 hospitalizations rose sharply again as early as September 2020 (Fig 3A and 3B).

233 The distribution of age groups varied throughout the observation period. In particular, the 234 age group of 80 years and above were most prevalent in the months of April, November and

235 December (Fig S4). Hospitalizations in which AKI was coded, were proportionately much 236 older, with the 80 years and above age group being the most represented (Fig S5).

237 Fig 2: A) Time course of age-standardized rates (per 100.00 person years) of overall

238 hospitalization, AKI and AKI-related mortality for COVID-19 in Germany (2020); B)

239 Standardized rate ratios (SRR) of AKI age-standardized rates (per 100.00 person years) and

240 AKI-related mortality in relation to the overall age-standardized COVID-19 hospitalization

241 rate in Germany (2020)

242 Fig 3: A) Time course of age-standardized rates (per 100.00 person years) of overall

243 hospitalization and overall mortality for COVID-19 in Germany (2020); B) Standardized rate

244 ratios (SRR) of overall mortality age-standardized rates (per 100.00 person years) in relation

245 to the overall age-standardized COVID-19 hospitalization rate in Germany (2020)

\section{Comorbidities}

247 The Elixhauser comorbidity index $(\mathrm{ECl})$ varied among the different groups. The mean $\mathrm{ECl}$ for

248 all COVID-19 associated hospitalizations was 1,2 (SD 3,1). For hospitalizations requiring

249 intensive care the mean $\mathrm{ECl}$ was 1,6 (SD 3,8). When acute kidney injury was present the $\mathrm{ECl}$

250 increased to $2,0(S D 3,8)$. In general, the four most common coded comorbidities were

251 uncomplicated hypertension (35,3\%), fluid and electrolyte disorders (20,6\%), uncomplicated

252 diabetes mellitus (13,3\%) and cardiac arrhythmias (10,0\%) (Fig 4). When acute kidney injury 
medRxiv preprint doi: https://doi.org/10.1101/2021.04.30.21256331; this version posted June 4, 2021. The copyright holder for this preprint (which was not certified by peer review) is the author/funder, who has granted medRxiv a license to display the preprint in perpetuity. It is made available under a CC-BY-NC-ND 4.0 International license .

or an ICU stay were coded, cardiac arrhythmias were relatively more prevalent compared to

all hospitalizations with COVID-19 (Fig S2, S3).

Fig 4: Relative frequencies of comorbidities in COVID-19 hospitalizations in Germany 2020.

chf: congestive heart failure; carit: cardiac arrhythmias; valv: valvular disease; pcd: pulmonary circulation disorders; pvd: peripheral vascular disorders; hypunc: hypertension - uncomplicated; hypc: hypertension - complicated; para: paralysis; ond: other neurological disorders; cpd: chronic pulmonary disease; diabunc: diabetes -uncomplicated; diabc: diabetes- complicated; hypothy: hypothyroidism; Id: liver disease; pud: peptic ulcer disease- excluding bleeding; aids: AIDS/HIV; lymph: lymphoma; metacanc: metastatic cancer; solidtum: solid tumour: without metastasis; rheumd: rheumatoid arthritis/collaged vascular disease; coag: coagulopathy; obes: obesity; wloss: weight loss; fed: fluid and electrolyte disorders; blane: blood loss anaemia; dane: deficiency anaemia; alcohol: alcohol abuse; drug: drug abuse; psycho: psychoses; depre: depression;

267 Our study for the first time provides nationwide data on COVID-19 hospitalizations and acute kidney injury in Germany in 2020. The key findings that emerge from our data are as follows. The highest proportion of hospitalizations associated with COVID-19 were in the age group over 80 years. The gender distribution was equal in COVID-19 related

271 hospitalization, however, we observed that men more often developed acute kidney injury

272 (RR 1,49 (95\% Cl 1,44-1,53)), needed ICU care and had a higher risk of in-hospital mortality

273 (RR: 1,30 (95\% $1,27-1,33))$ than women. Our results thus exhibit a gender bias. This is

274 consistent with a meta-analysis including 3.111.714 COVID-19 associated hospitalizations

275 worldwide, which identified male sex as a risk factor for death and ICU-admission, despite

276 the gender ratio being equal at the time of admission (21). Different underlying

277 mechanisms - from hormonal, genetic to behavioral effects and risk factor prevalence -

278 have been discussed in the literature $(21,22)$. 
medRxiv preprint doi: https://doi.org/10.1101/2021.04.30.21256331; this version posted June 4, 2021. The copyright holder for this preprint (which was not certified by peer review) is the author/funder, who has granted medRxiv a license to display the preprint in perpetuity. It is made available under a CC-BY-NC-ND 4.0 International license .

279 Overall, $19 \%$ of all hospitalizations needed intensive care treatment. This fraction was

280 particularly high in patients with acute kidney injury. This finding is in line with other studies

281 (23,24). There are no clearly defined criteria for ICU admission in COVID-19 hospitalized

282 patients. Germany possesses the highest capacity of intensive care beds in all OECD-

283 countries. Despite the presumably higher availability of ICU capacity, this fact did not lead to 284 higher utilization of these capacities. This could be an indicator that the percentage of 285 critically ill patients was similar compared to different countries (23).

286 Occurrence of AKI considerably differs in previous studies, partly due to a different 287 definition of AKI. Our analysis showed that $10.9 \%$ of all hospitalizations experienced acute 288 kidney injury. The incidence of AKI in this national series is lower than what has been 289 reported in regionally confined studies from the United States $(8,9,23)$. A meta-analysis by 290 Gabarre et al. (2) rendered similar results to our figures. They observed an average AKI 291 incidence of $11 \%(95 \% \mathrm{Cl} 8-17 \%)$ overall, with highest ranges in the critically ill $(23 \%(95 \% \mathrm{Cl}$ 292 14-35\%)). Nevertheless, the age structure, risk factor prevalence and the burden of COVID29319 during the observation period differ relevantly between countries and the AKI rate is 294 therefore only comparable to a limited extend.

295 A large proportion of patients with acute kidney injury suffered severe kidney injury (AKIN

296 Stage 3: 40,6\%), this is consistent with previous findings (9). In the group of hospitalization 297 with AKI 49,9\% required ICU admission compared to $15,2 \%$ of patients without AKI. The 298 relative risk to be treated in an ICU was 3,27 for AKI patients. Moreover, in the group with $299 \mathrm{AKI}, 42,0 \%$ required mechanical ventilation. Data from the early phase of the pandemic in 300 New York state estimated that $53,6 \%$ of AKI patients needed invasive ventilation (10). This 301 higher numbers are likely reflective of more severe disease outcomes in patients with AKI. 
medRxiv preprint doi: https://doi.org/10.1101/2021.04.30.21256331; this version posted June 4, 2021. The copyright holder for this preprint (which was not certified by peer review) is the author/funder, who has granted medRxiv a license to display the preprint in perpetuity. It is made available under a CC-BY-NC-ND 4.0 International license .

302 RRT was required in $2,2 \%$ of all hospitalizations. Among patients with AKI $20,5 \%$ required

303 RRT. This figure is consistent with data from various studies $(6,9,25)$. The majority $(88,5 \%)$ of

304 the RRT was performed in the intensive care unit. $69,1 \%$ of all patients requiring dialysis

305 needed invasive ventilation. Similar findings were reported in a multi-center cohort study

306 from the United States (6). Previous studies suggested that there is an association between

307 mechanical ventilation, AKI and RRT. RRT often occurs around time of intubation, suggesting

308 a role for altered hemodynamics in this situation $(6,10)$. Hence, vasopressors are often 309 initiated around this time.

310 The overall in-hospital mortality for COVID-19 associated hospitalizations vary across

311 different countries and cohorts, showing differences in testing and case identification,

312 variable thresholds for hospitalization and staff capacities. Therefore, differences in in-

313 hospital mortality ranged between 15 to $20 \%(26,27)$. Our analysis showed that 30.300

314 (19.7\%) of hospitalizations with COVID-19 ultimately deceased, of 154.170 initially admitted

315 to hospital. In-hospital mortality was $57.9 \%$ among patients with AKI versus $15 \%$ among

316 those without AKI. This finding underlines the poor prognosis of these patients and the 317 severity of disease.

318 The age-standardized hospitalization rate due to COVID-19 in 2020 was bimodally shaped,

319 with peak rates in April and November. This observation is congruent with the incidence

320 figures reported by the Robert Koch Institute (28). The first peak with increasing mortality

321 rates in March and April was followed by a decline in mortality rates and a concomitant

322 decrease in hospital admissions. Similar results have already been demonstrated in various

323 studies from other countries. In a data-analysis from the United States a decrease in the

324 risk-adjusted mortality was observed, ranging from $16.56 \%$ to $9.29 \%$ in the early period of 
medRxiv preprint doi: https://doi.org/10.1101/2021.04.30.21256331; this version posted June 4, 2021. The copyright holder for this preprint (which was not certified by peer review) is the author/funder, who has granted medRxiv a license to display the preprint in perpetuity. It is made available under a CC-BY-NC-ND 4.0 International license .

325 this study (January through April 2020) compared with the later period (May through June

326 2020) (29). Further, national ICU data from the United Kingdom - published as a preprint up

327 to now - confirmed this finding. The authors found a reduction in mortality rates from $41,4 \%$

328 in March 2020 to 24,8\% in June 2020 (30). The underlying reason for the decrease of

329 mortality rates is not obvious and certainly multifactorial. One important factor was

330 certainly the concomitant decline in the incidence rate in the UK and the US. For example, a

331 large US study of health insurance data, involving more than 38.517 patients, revealed that

332 the strongest determinant of improvements in in-hospital outcome was a decline in

333 community rates of infection (29). Other reasons might be a shift in demographics,

334 experience in physicians to early diagnose and treat COVID-19 patients, hospitals and staff

335 became less overwhelmed during time. In our data during the second peak in COVID-19

336 hospitalizations, which was more pronounced than the first, the in-hospital mortality rate

337 increased steadily from September to December and exceeded the COVID-19 associated in-

338 hospital mortality in March and April markedly (5,36 per 100.000 person years in April and

33916,15 per 100.000 person years in December). One can only speculate about the factors that

340 led to this development. One, but certainly not the only, explanation could be a different

341 age distribution of patients admitted to the hospital with a higher proportion of older

342 patients in November and December, as in our data (Fig S4, Fig S5). Further, multiple factors

343 might have influenced in-hospital mortality. The increasing number of patients in need of

344 critical care could have overwhelmed hospitals regionally, which happened for example in

345 Saxony, Germany in December 2020. As already mentioned, an American study has shown

346 that hospitals did better when the prevalence of COVID-19 in their surrounding

347 communities was lower(29). Another contributing factor could have been staff shortages

348 driven by COVID-19 infections, school lockdowns, quarantine regulations and the necessity 
medRxiv preprint doi: https://doi.org/10.1101/2021.04.30.21256331; this version posted June 4, 2021. The copyright holder for this preprint (which was not certified by peer review) is the author/funder, who has granted medRxiv a license to display the preprint in perpetuity. It is made available under a CC-BY-NC-ND 4.0 International license .

349 to take care of relatives infected with COVID-19 or in quarantine. In contrast to the

350 development discussed above, the ASR for AKI and AKI-related mortality had a

351 disproportionately smaller increase and were already declining in December. The age

352 distribution in our cohort was similar among all hospitalized patients, with a higher

353 proportion of elderly patients in the second peak in October, November and December in 354 comparison to February, March and April. Thus, differences in age distribution is not a good 355 explanation for this finding (S4 Fig and S5). At this point, it must be said again that multiple 356 factors could have influenced the ASR for AKI und AKI-related mortality. Apart from 357 differences in the patient population or age distribution, changes in the treatment strategy 358 e.g., the early use of drug therapies for patients with an increased risk of severe COVID-19 359 courses.

360 The mean length of stay (LOS- discharged or dead) of all patients was 11,3 days and 361 increased with AKI to 18,4 days. LOS varies in different studies, and - according to a 362 systematic review by Rees et al. (31) - the median LOS was 14 days in China, compared with 3635 (IQR 3-9) days outside of China. Similar figures were reported by Fisher et al. (8). This may 364 be explained by many differences in criteria for admission and discharge between countries, 365 and different timings in the course of the pandemic. Hospital capacities in Germany were 366 not overwhelmed by the pandemic, and the pressure to discharge patients might have been 367 lower. The most comprehensive analysis of German patients to date included 10.021 368 patients with a mean LOS of 14,3 days (32). This was longer than in our analysis, an 369 explanation for the discrepancy could be timing of data collection. Karagiannidis et al. 370 collected their data at the beginning of the pandemic. Due to an increasing experience in 
medRxiv preprint doi: https://doi.org/10.1101/2021.04.30.21256331; this version posted June 4, 2021. The copyright holder for this preprint (which was not certified by peer review) is the author/funder, who has granted medRxiv a license to display the preprint in perpetuity. It is made available under a CC-BY-NC-ND 4.0 International license .

371 treating COVID-19 patients and new treatment options, the length of stay consequently 372 declined.

373 The observed comorbidities varied between the different groups. Hypertension, diabetes 374 mellitus, fluid and electrolyte disorders and cardiac arrhythmias were the most commonly 375 coded comorbidities. This finding is plausible, as these are the most common comorbidities

376 in patients with chronic kidney disease (33) and likewise known risk factors for

377 hospitalization with COVID-19 (34). Cardiac arrhythmias became more prevalent in

378 hospitalizations with AKI. Cardiac arrhythmias are a common finding in COVID-19, in 379 particular with an increasing number of comorbidities (35).

381 The major strength of this study is that we provide a nationwide population-based view on

382 COVID-19 hospitalizations with acute kidney injury in Germany. We retrieved DRG-data

383 covering virtually every hospital in Germany. In this study, we use routine hospitalization

384 data, which is lacking clinical detail. This might lead to confounding that we could not adjust 385 for. The InEK provides aggregated data due to data safety precautions, which is fully 386 anonymized. It is, therefore, possible that this could lead to bias caused by readmission, 387 though this possibility is limited, because of the severity of most cases and our efforts to 388 exclude readmissions from the dataset. Another important fact to consider, when analyzing

389 routine data, is the observation period. In our analysis the observation period ends in the 390 midst of the second wave of the COVID-19 pandemic in Germany. This will lead to bias, as

391 the outcome of these cases remains unknown, in particular for hospitalizations in the last 392 month of the observation period. 
medRxiv preprint doi: https://doi.org/10.1101/2021.04.30.21256331; this version posted June 4, 2021. The copyright holder for this preprint (which was not certified by peer review) is the author/funder, who has granted medRxiv a license to display the preprint in perpetuity.

It is made available under a CC-BY-NC-ND 4.0 International license.

394 
medRxiv preprint doi: https://doi.org/10.1101/2021.04.30.21256331; this version posted June 4, 2021. The copyright holder for this preprint (which was not certified by peer review) is the author/funder, who has granted medRxiv a license to display the preprint in perpetuity.

It is made available under a CC-BY-NC-ND 4.0 International license .

395

396

397

398

400

401

402

403

404

405

406

407

408

409

410

411

412

413

414

415

416

417

418

\section{Bibliography}

1. Richardson S, Hirsch JS, Narasimhan M, Crawford JM, McGinn T, Davidson KW, et al. Presenting Characteristics, Comorbidities, and Outcomes among 5700 Patients Hospitalized with COVID-19 in the New York City Area. JAMA - Journal of the American Medical Association. 2020;323(20):2052-9.

2. Gabarre P, Dumas G, Dupont T, Darmon M, Azoulay E, Zafrani L. Acute kidney injury in critically ill patients with COVID-19. Intensive Care Medicine [Internet]. 2020;46(7):1339-48. Available from: https://doi.org/10.1007/s00134-020-06153-9

3. Wang L, Li X, Chen H, Yan S, Li D, Li Y, et al. Coronavirus disease 19 infection does not result in acute kidney injury: An analysis of 116 hospitalized patients from Wuhan, China. American Journal of Nephrology. 2020;51(5):343-8.

4. Yang $X$, Jin $Y, L i R$, Zhang $Z$, Sun $R$, Chen $D$. Prevalence and impact of acute renal impairment on COVID-19: A systematic review and meta-analysis. Critical Care. $2020 ; 24(1): 1-8$

5. Zhou F, Yu T, Du R, Fan G, Liu Y, Liu Z, et al. Clinical course and risk factors for mortality of adult inpatients with COVID-19 in Wuhan, China: a retrospective cohort study. The Lancet [Internet]. 2020;395(10229):1054-62. Available from: http://dx.doi.org/10.1016/S0140-6736(20)30566-3

6. Gupta S, Coca SG, Chan L, Melamed ML, Brenner SK, Hayek SS, et al. AKI treated with renal replacement therapy in critically ill patients with COVID-19. Journal of the American Society of Nephrology. 2021;32(1):161-76.

7. Thakkar J, Chand S, Aboodi MS, Gone AR, Alahiri E, Schecter DE, et al. Characteristics, Outcomes and 60-Day Hospital Mortality of ICU Patients with COVID-19 and Acute Kidney Injury. Kidney360. 2020;1(12):1339-44. 
medRxiv preprint doi: https://doi.org/10.1101/2021.04.30.21256331; this version posted June 4, 2021. The copyright holder for this preprint (which was not certified by peer review) is the author/funder, who has granted medRxiv a license to display the preprint in perpetuity.

It is made available under a CC-BY-NC-ND 4.0 International license .

419 8. Fisher M, Neugarten J, Bellin E, Yunes M, Stahl L, Johns TS, et al. AKI in Hospitalized http://jasn.asnjournals.org/content/31/9/2145.abstract

9. Chan L, Chaudhary K, Saha A, Chauhan K, Vaid A, Zhao S, et al. AKI in hospitalized patients with COVID-19. Journal of the American Society of Nephrology. 2021;32(1):151-60.

10. Hirsch JS, Ng JH, Ross DW, Sharma P, Shah HH, Barnett RL, et al. Acute kidney injury in patients hospitalized with COVID-19. Kidney International. 2020;98(1):209-18.

11. Karagiannidis C, Mostert C, Hentschker C, Voshaar T, Malzahn J, Schillinger G, et al. Case characteristics, resource use, and outcomes of 10â€^021 patients with COVID-19 www.thelancet.com/respiratoryVol

12. Graubner B, Auhuber TC. ICD-10-GM Version 2020, Systematisches Verzeichnis, Internationale statistische Klassifikation der Krankheiten und verwandter

Gesundheitsprobleme, 10. Revision, Stand: 20. September 2019 [Internet]. Köln: Bundesinstitut für Arzneimittel und Medizinprodukte (BfArM) im Auftrag des

441 13. Operationen- und Prozedurenschlüssel Internationale Klassifikation der Prozeduren 
medRxiv preprint doi: https://doi.org/10.1101/2021.04.30.21256331; this version posted June 4, 2021. The copyright holder for this preprint (which was not certified by peer review) is the author/funder, who has granted medRxiv a license to display the preprint in perpetuity. It is made available under a CC-BY-NC-ND 4.0 International license .

443 Arzneimittel und Medizinprodukte (BfArM) im Auftrag des Bundesministeriums für 444 Gesundheit (BMG) unter Beteiligung der Arbeitsgruppe ICD des Kuratoriums für 445 Fragen der Klassifikation im Gesundheitswesen (KKG); 2020. 740. Available from: 446 https://www.dimdi.de/dynamic/de/klassifikationen/icd/icd-10-gm/

447 14. Busse R, Nimptsch U. COVID-19-Pandemie: Historisch niedrige Bettenauslastung. 448 Deutsches Aerzteblatt Online. 2021;118(10):10-3.

449 15. Levin A, Warnock DG, Mehta RL, Kellum JA, Shah S v., Molitoris BA, et al. Improving 450 Outcomes From Acute Kidney Injury: Report of an Initiative. American Journal of $451 \quad$ Kidney Diseases. 2007;50(1):1-4.

452 16. Gesundheitsberichterstattung des Bundes [Internet]. 2021. Available from: https://www.gbe-bund.de/gbe/pkg_isgbe5.prc_isgbe

454 17. Quan H, Sundararajan V, Halfon P, Fong A. Coding algorithms for defining comorbidities in. Medical Care [Internet]. 2005;43(11). Available from: http://scholar.google.com/scholar?hl=en\&btnG=Search\&q=intitle:Coding+Algorithms +for+Defining+Comorbidities+in\#1\%5Cnhttp://scholar.google.com/scholar?hl=en\&bt $n G=S e a r c h \& q=i n t i t l e: C o d i n g+$ algorithms+for+defining+comorbidities+in\#1 Vienna, Austria: R Foundation for Statistical Computing; 2020. Available from: www.rproject.org

462 19. Tomas J. Aragon. epitools: Epidemiology Tools. R package version 0.5-10.1. 2020.

463 20. Stevenson M, Sergeant E. epiR - Tools for the Analysis of Epidemiological Data. 2021.

464 21. Peckham H, de Gruijter NM, Raine C, Radziszewska A, Ciurtin C, Wedderburn LR, et 465 al. Male sex identified by global COVID-19 meta-analysis as a risk factor for death and 
medRxiv preprint doi: https://doi.org/10.1101/2021.04.30.21256331; this version posted June 4, 2021. The copyright holder for this preprint (which was not certified by peer review) is the author/funder, who has granted medRxiv a license to display the preprint in perpetuity. It is made available under a CC-BY-NC-ND 4.0 International license .

ITU admission. Nature Communications [Internet]. 2020;11(1):1-10. Available from: http://dx.doi.org/10.1038/s41467-020-19741-6

468 22. Kelada M, Anto A, Dave K, Saleh SN. The Role of Sex in the Risk of Mortality From COVID-19 Amongst Adult Patients: A Systematic Review. Cureus. 2020;12(8).

23. Richardson S, Hirsch JS, Narasimhan M, Crawford JM, McGinn T, Davidson KW, et al. Presenting Characteristics, Comorbidities, and Outcomes Among 5700 Patients Hospitalized With COVID-19 in the New York City Area. JAMA [Internet]. 2020;323:2052-9. Available from: https://jamanetwork.com/

24. Fisher M, Neugarten J, Bellin E, Yunes M, Stahl L, Johns TS, et al. AKI in Hospitalized Patients with and without COVID-19: A Comparison Study. Journal of the American Society of Nephrology [Internet]. 2020 Sep 1;31(9):2145 LP - 2157. Available from:

25. Richards-Belle A, Orzechowska I, Doidge J, Thomas K, Harrison DA, Koelewyn A, et al. Critical care outcomes, for the first 200 patients with confirmed COVID-19, in

England, Wales and Northern Ireland: A report from the ICNARC Case Mix Programme. Journal of the Intensive Care Society. 2020;0(0):1-10.

26. Wiersinga WJ, Rhodes A, Cheng AC, Peacock SJ, Prescott HC. Pathophysiology, Transmission, Diagnosis, and Treatment of Coronavirus Disease 2019 (COVID-19): A Review. JAMA - Journal of the American Medical Association. 2020;324(8):782-93.

27. Sorci G, Faivre B, Morand S. Explaining among-country variation in COVID-19 case fatality rate. Scientific Reports. 2020 Dec 1;10(1).

28. Robert Koch Institut. Total overview of cases, deaths, and 7-day incidences reported per day to the RKI by state and county. [Internet]. 2021. Available from: https://www.rki.de/DE/Content/InfAZ/N/Neuartiges_Coronavirus/Daten/Fallzahlen_ 
medRxiv preprint doi: https://doi.org/10.1101/2021.04.30.21256331; this version posted June 4, 2021. The copyright holder for this preprint (which was not certified by peer review) is the author/funder, who has granted medRxiv a license to display the preprint in perpetuity. It is made available under a CC-BY-NC-ND 4.0 International license .

Daten.html;jsessionid=4D411DFBB2E2575A9CD1F5504E7CE3BC.internet052?nn=134 90888

492 29. Asch DA, Sheils NE, Islam MN, Chen Y, Werner RM, Buresh J, et al. Variation in US Hospital Mortality Rates for Patients Admitted with COVID-19 during the First 6 Months of the Pandemic. JAMA Internal Medicine. 2020;19104(4):471-8.

30. Dennis JM, McGovern AP, Vollmer SJ, Mateen BA. Improving COVID-19 critical care mortality over time in England: A national cohort study, March to June 2020. medRxiv. 2020;44(0).

31. Rees EM, Nightingale ES, Jafari Y, Waterlow NR, Clifford S, Pearson CAB, et al. COVID19 length of hospital stay: A systematic review and data synthesis. medRxiv. 2020; admitted to 920 German hospitals: an observational study. The Lancet Respiratory medicine [Internet]. 2020 Sep [cited 2021 Mar 11];8(9):853-62. Available from:

33. Reichel H, Zee J, Tu C, Young E, Pisoni RL, Stengel B, et al. Chronic kidney disease progression and mortality risk profiles in Germany: Results from the Chronic Kidney Disease Outcomes and Practice Patterns Study. Nephrology Dialysis Transplantation.

509 34. Ioannou GN, Locke E, Green P, Berry K, O’Hare AM, Shah JA, et al. Risk Factors for 510 Hospitalization, Mechanical Ventilation, or Death Among 10?131 US Veterans With SARS-CoV-2 Infection. JAMA network open. 2020;3(9):e2022310. 
medRxiv preprint doi: https://doi.org/10.1101/2021.04.30.21256331; this version posted June 4, 2021. The copyright holder for this preprint (which was not certified by peer review) is the author/funder, who has granted medRxiv a license to display the preprint in perpetuity. It is made available under a CC-BY-NC-ND 4.0 International license.

512 35. Coromilas EJ, Kochav S, Goldenthal I, Biviano A, Garan H, Goldbarg S, et al. $513 \quad$ Worldwide Survey of COVID-19 Associated Arrhythmias. Circulation: Arrhythmia and $514 \quad$ Electrophysiology. 2021;(March):285-95.

515

516 
medRxiv preprint doi: https://doi.org/10.1101/2021.04.30.21256331; this version posted June 4, 2021. The copyright holder for this preprint (which was not certified by peer review) is the author/funder, who has granted medRxiv a license to display the preprint in perpetuity. It is made available under a CC-BY-NC-ND 4.0 International license .

\section{Supporting information}

518 S1 Fig. Age-specific mortality rates of COVID-19 hospitalizations in Germany 2020 (per

519100.000 person years)

520 S2 Fig. Relative frequencies of comorbidities in COVID-19 hospitalizations with AKI in

521 Germany 2020.

522 chf: congestive heart failure; carit: cardiac arrhythmias; valv: valvular disease; pcd: pulmonary circulation 523 disorders; pvd: peripheral vascular disorders; hypunc: hypertension - uncomplicated; hypc: hypertension 524 - complicated; para: paralysis; ond: other neurological disorders; cpd: chronic pulmonary disease; 525 diabunc: diabetes -uncomplicated; diabc: diabetes- complicated; hypothy: hypothyroidism; Id: liver 526 disease; pud: peptic ulcer disease- excluding bleeding; aids: AIDS/HIV; lymph: lymphoma; metacanc: 527 metastatic cancer; solidtum: solid tumour: without metastasis; rheumd: rheumatoid arthritis/collaged 528 vascular disease; coag: coagulopathy; obes: obesity; wloss: weight loss; fed: fluid and electrolyte 529 disorders; blane: blood loss anaemia; dane: deficiency anaemia; alcohol: alcohol abuse; drug: drug abuse; 530 psycho: psychoses; depre: depression;

531

532 S3 Fig. Relative frequencies of comorbidities in COVID-19 hospitalizations with ICU treatment in Germany 2020.

534 chf: congestive heart failure; carit: cardiac arrhythmias; valv: valvular disease; pcd: pulmonary circulation disorders; pvd: peripheral vascular disorders; hypunc: hypertension - uncomplicated; hypc: hypertension - complicated; para: paralysis; ond: other neurological disorders; cpd: chronic pulmonary disease; diabunc: diabetes -uncomplicated; diabc: diabetes- complicated; hypothy: hypothyroidism; Id: liver disease; pud: peptic ulcer disease- excluding bleeding; aids: AIDS/HIV; lymph: lymphoma; metacanc: metastatic cancer; solidtum: solid tumour: without metastasis; rheumd: rheumatoid arthritis/collaged vascular disease; coag: coagulopathy; obes: obesity; wloss: weight loss; fed: fluid and electrolyte disorders; blane: blood loss anaemia; dane: deficiency anaemia; alcohol: alcohol abuse; drug: drug abuse; 542 psycho: psychoses; depre: depression;

544 S4 Fig. Percentage distribution of age groups during the observation period (Overall COVID-

546 S5 Fig. Percentage distribution of age groups during the observation period (AKI)

547 S1 Table. List of ICD-10-GM and OPS Codes, version 2020

548 S2 Table. Contingency table AKI by sex 
medRxiv preprint doi: https://doi.org/10.1101/2021.04.30.21256331; this version posted June 4, 2021. The copyright holder for this preprint (which was not certified by peer review) is the author/funder, who has granted medRxiv a license to display the preprint in perpetuity.

It is made available under a CC-BY-NC-ND 4.0 International license.

549 S3 Table. Contingency table in-hospital mortality by sex 

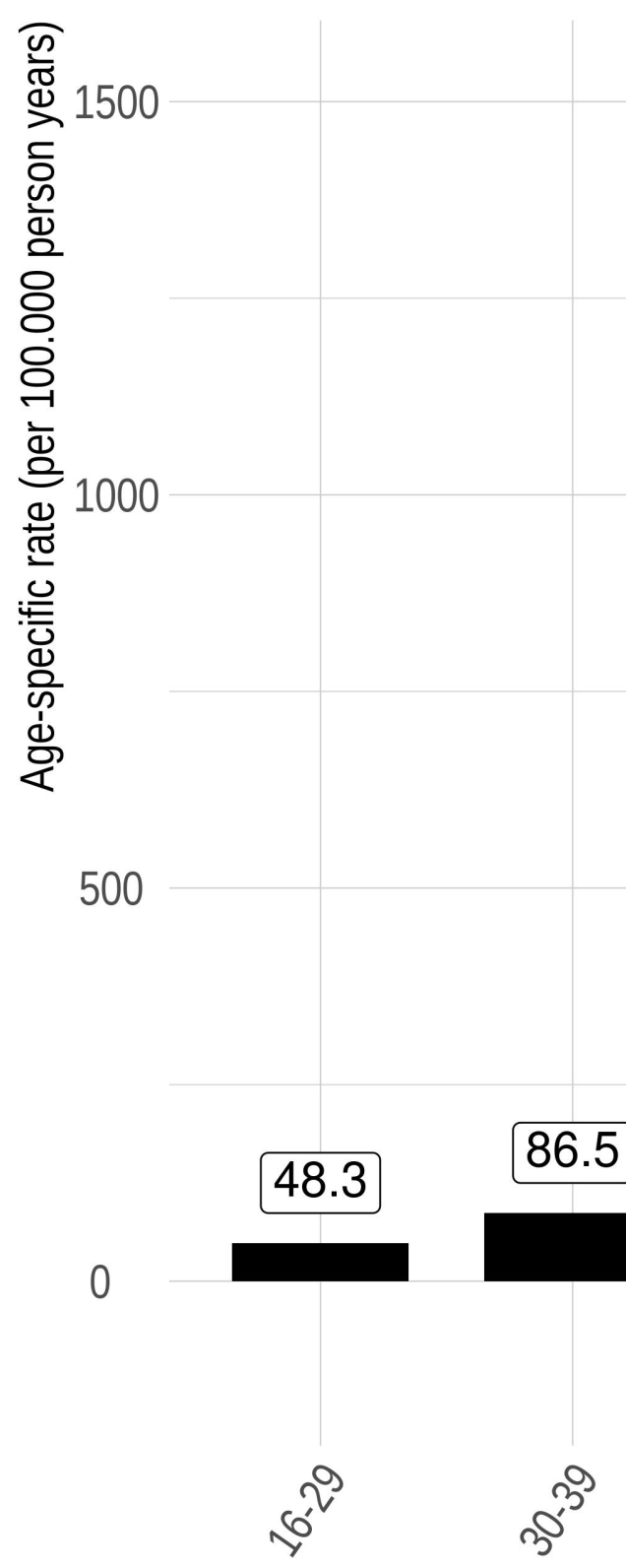

$x^{x}$

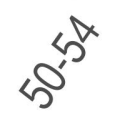

ऊक

$6^{66^{\alpha}}$

$\sigma^{\alpha}$

ง 
A

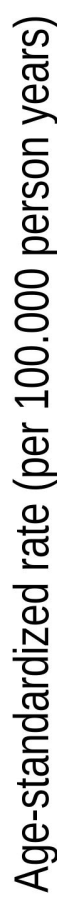

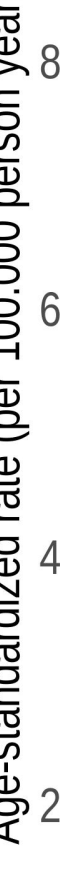

0
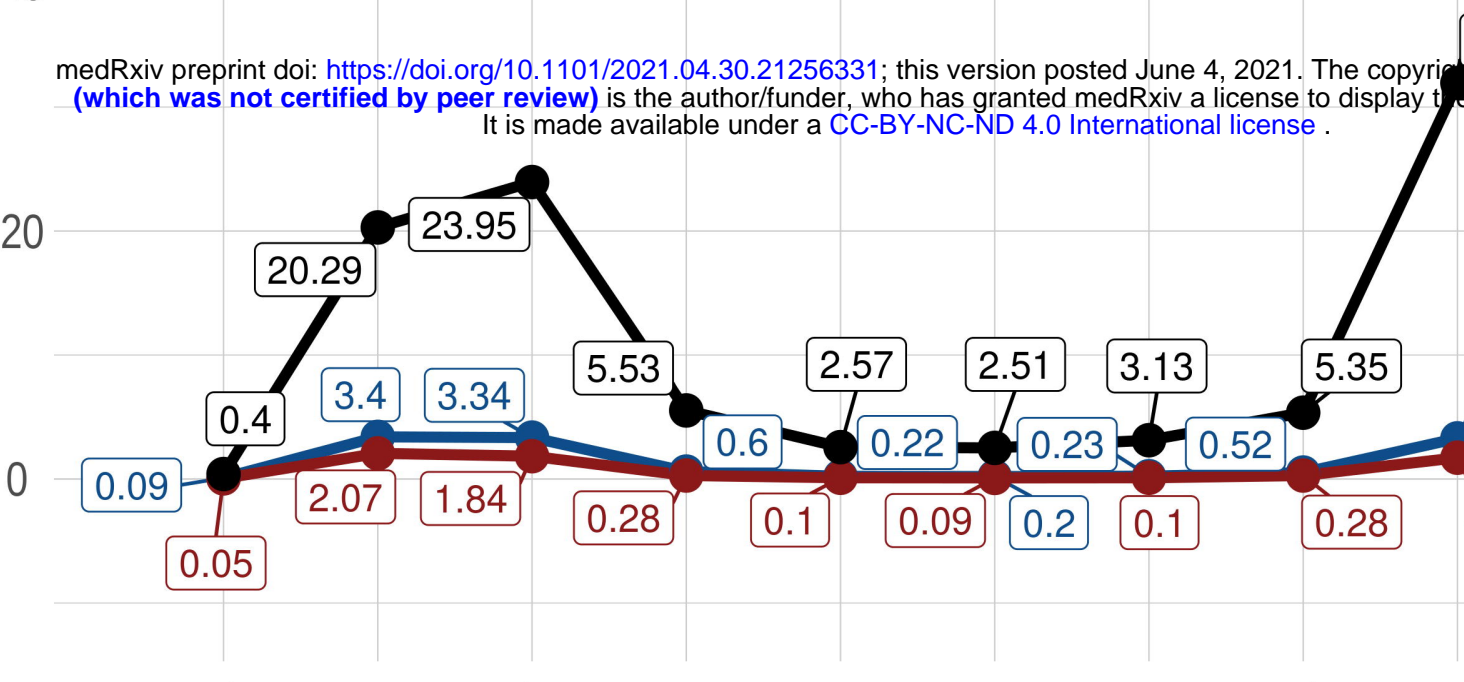

$$
31.94
$$

or this preprint

(which was not certified by peer review) is the author/funder, who has granted medRxiv a license to display

preprint in perpetuity.

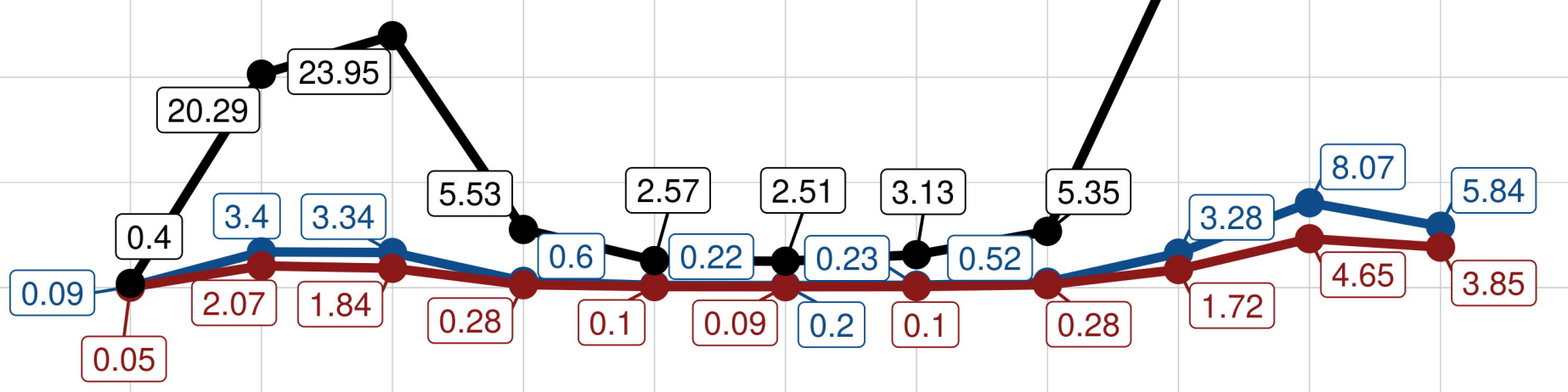

made available under a CC-BY-NC-ND 4.0 International license.

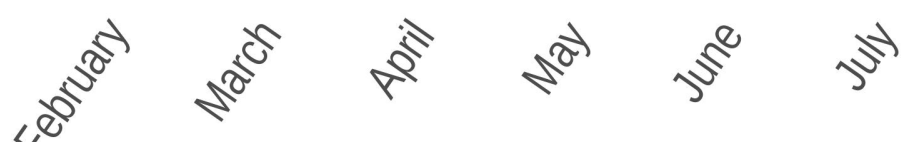
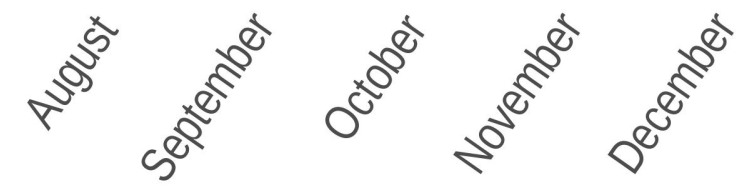

B

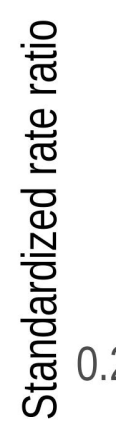

B
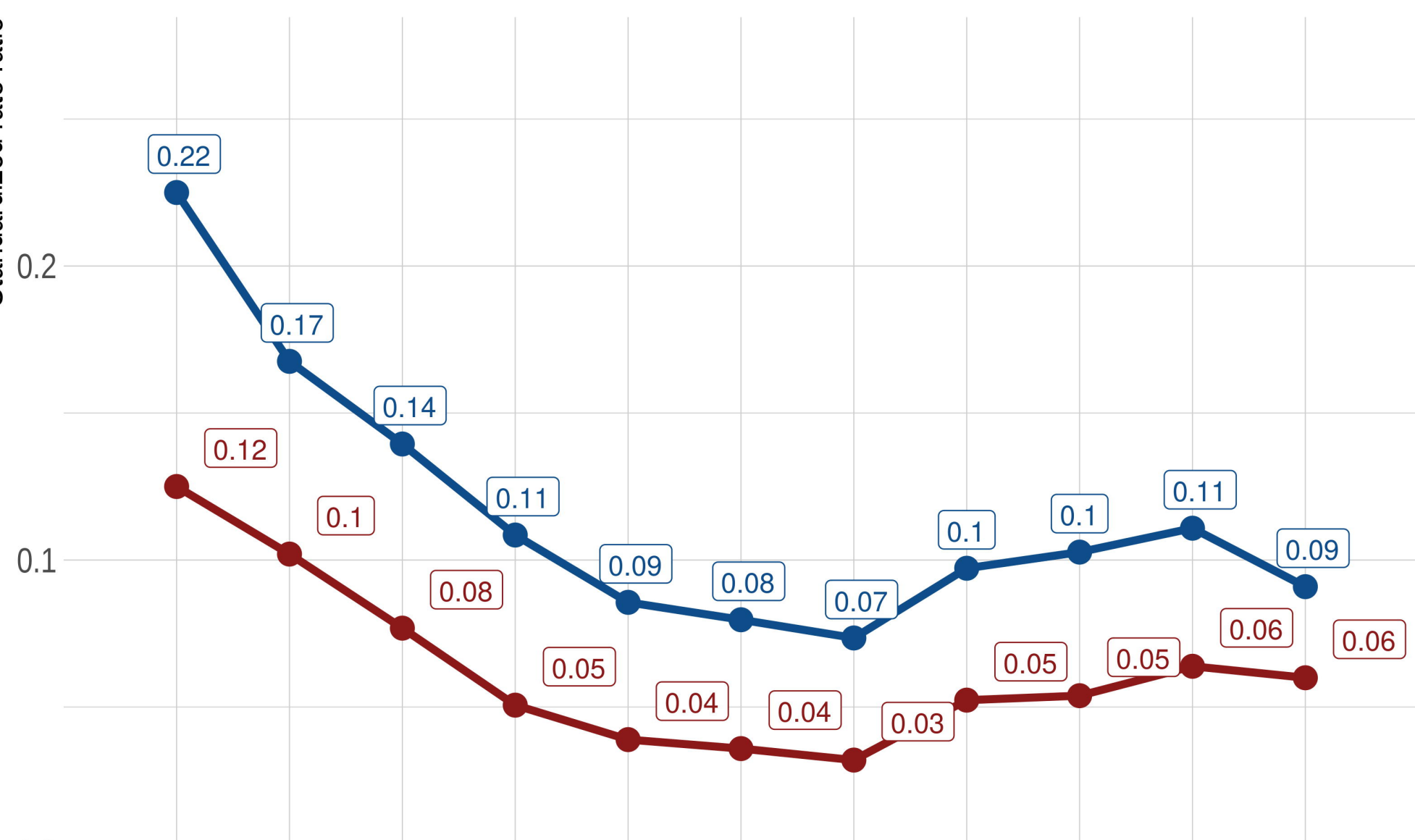

0.0

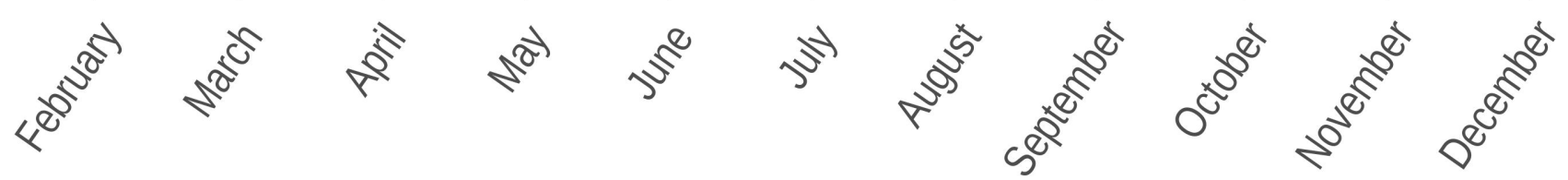


A

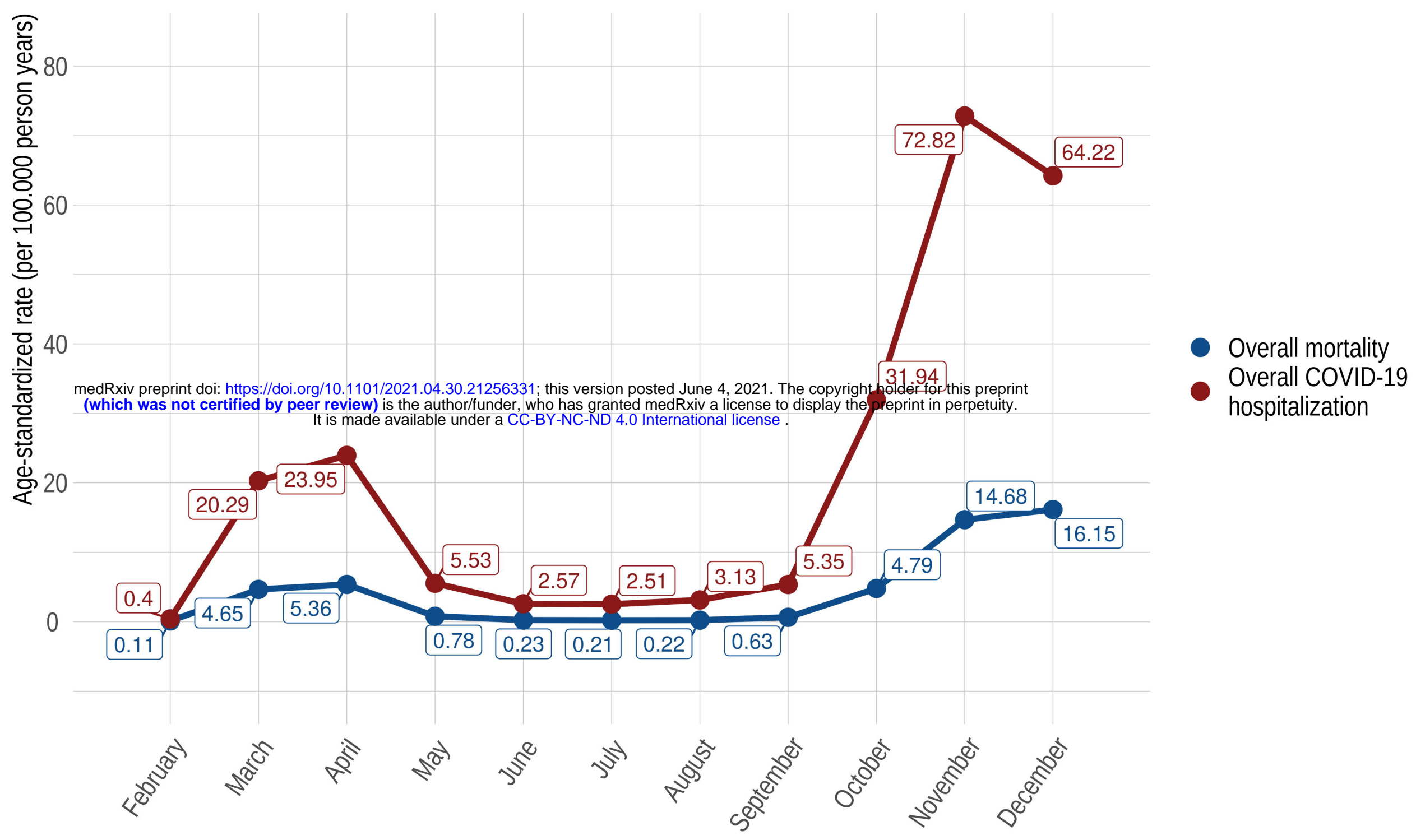

B

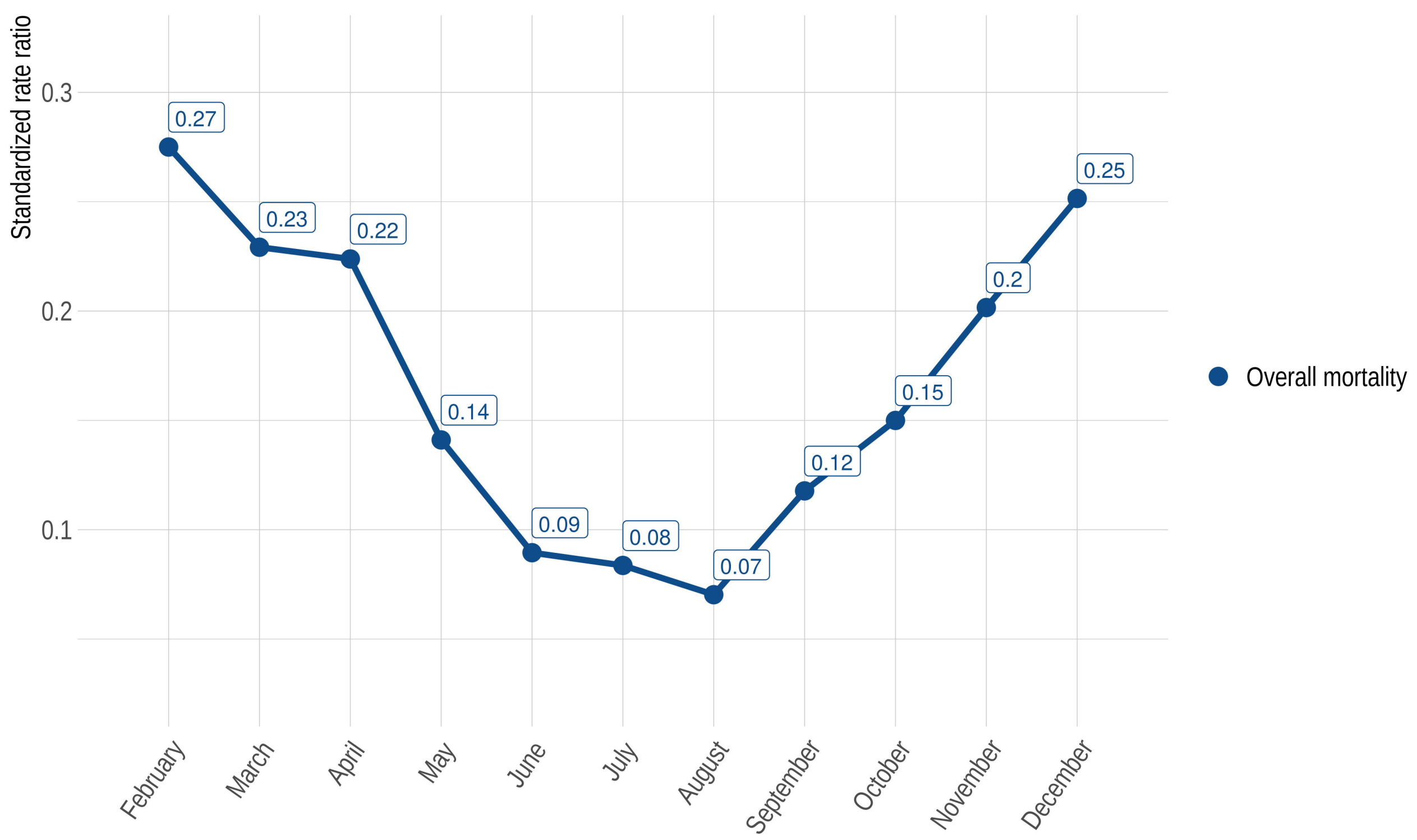



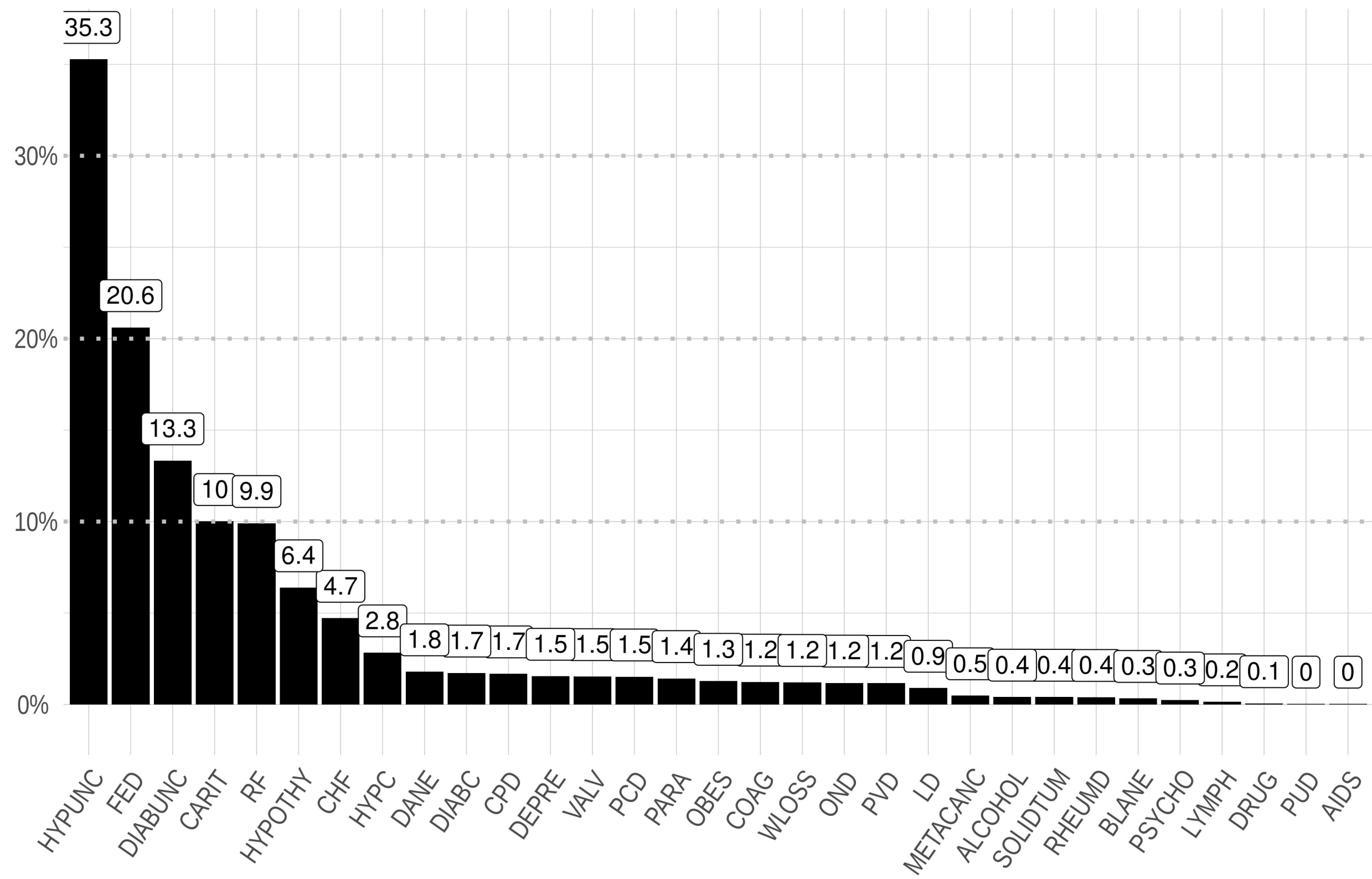